\title{
MUERTE EN EL LORETO. CIUDADANÍA ARMADA Y VIOLENCIA POLÍTICA EN BOLIVIA (1861-1862)
}

POR

\author{
MARTA IRUROZQUI \\ GEA, IH-CSIC
}

Los casos de la Matanza del Loreto y del posterior ajusticiamiento popular de su responsable ilustran cómo la conversión del vecindario paceño en el pueblo en armas combatió tanto el abuso partidista del poder, como la ruptura de la legalidad constitucional ejercida por las revoluciones militaristas. El pueblo en la calle y el pueblo representado en una junta de gobierno contribuyeron a la institucionalización del Estado - expresada en la política de fusión-al actuar armada y asociativamente contra el militarismo golpista, tomándose también la acción política en un medio contra la devaluación laboral y de estatus de los artesanos.

Palabras Clave: Matanzas Yáñez, ciudadano armado, política de fusión, junta, municipio, revolución militarista, pueblo, artesanos, Bolivia.

«La realización de los principios democráticos, por medio de la fusión. Marchemos pues unidos a conseguirlo, sin reconocer más partido que la felicidad de la patria. En La Actualidad hemos enarbolado La Bandera Tricolor para sostener La Causa de los Pueblos por medio de La Concordia y comenzamos ya a vislumbrar El Crepúsculo de un claro y hermoso día» ${ }^{2}$.

La prensa boliviana de la época llamó Matanzas del Loreto a las ejecuciones que por orden de Plácido Yáñez, Comandante General de La Paz, se realizaron en esta ciudad la noche del 23 de octubre de 1861. Las víctimas fueron cincuenta y cinco prisioneros políticos seguidores del partido belcista - lide-

1 Proyectos de investigación I+D: HUM2006-01703/CISO y HUM2006-10136.

2 Apoyo del periódico paceño a la politica de fusión de Achá mediante un juego de palabras con los principales periódicos del momento. La Bandera Tricolor, La Paz, 7 de abril de 1861. 
rado por los ex presidentes Manuel Isidoro Belzu (1848-55) y Jorge Córdova (1856-58) - , encarcelados en el Templo del Loreto, los cuarteles Segundo y de policía y la cárcel entre los días 29 de septiembre y 23 de octubre bajo la acusación de preparar una revolución contra la presidencia provisoria del general José María de Achá. Un mes más tarde, en medio de un enfrentamiento militar entre los simpatizantes del gobierno y las fuerzas rebeldes del coronel Narciso Balza, Yáñez fue buscado y asediado por una masa popular para ajusticiarlo por los crímenes cometidos. Logrado su objetivo, la población involucrada en la persecución no sólo no tomó partido en la contienda militar, sino que colaboró con otras instancias civiles de la ciudad para lograr una pacificación de la misma que se concretó en el reconocimiento de Achá como legítimo representante de la nación.

Este texto aborda los sucesos mencionados con el objetivo de reflexionar sobre los procesos de legitimación y deslegitimación del ejercicio público de la violencia política por parte de gobernantes y gobernados. Para ello se centra en dos manifestaciones de la misma vinculadas al ejercicio de la ciudadanía ${ }^{3}$ y al enfrentamiento entre partidos, que fueron aceptadas socialmente al transformar a la población en soldados: la militarista, unida a la acción profesional de los ejércitos de línea, y la popular, asociada a la acción de los civiles. Aunque ambos tipos de violencia reivindicaban al ciudadano armado, no compartían igual concepción del mismo. El primer caso remitía al cesarismo militar. Sólo podían ser considerados ciudadanos armados los militares sublevados que gracias a defender un orden originario vulnerado se convertían en los depositarios de las garantías del pueblo. Si bien en un inicio, bajo la concepción de que la salvación de la patria era una responsabilidad colectiva, todos los individuos debían convertirse en ciudadanos armados, de acuerdo con el principio de libertad sólo fueron reconocidos así los jefes militares responsables de una asonada y no los soldados reclutados en el ejército mediante levas. En el segundo caso eran ciudadanos armados todos los civiles en armas, tanto los agrupados en guardias nacionales y milicias de vecinos, como los organizados coyunturalmente frente a un acto que atentara contra el bien común ${ }^{4}$. Con independencia de la diferencia expuesta, desde la formación de la república los dos tipos de violencia política interactuaron bajo la noción de revolución. Con ello se

3 Irurozqui, 2005: 33-75; 70/2 (Madrid, 2008): 62-68.

4 A lo largo del siglo XIX ambos componentes del ciudadano armado sufrieron un proceso de descrédito que convirtió al primero en «la soldadesca pretoriana» y al segundo en «la plebe proselitista», quedando explicado el mismo por el origen étnico — indígena y mestizo- de sus componentes, incapaces por lo mismo de «practicar y comprender los deberes republicanos» y culpables por tanto de producir «arbitrariedad y anarquía». Arguedas, 1959: 110. 
creó una autoconciencia racional y normativa de la guerra asociada al amor a la patria y, por tanto, a la defensa de la nación y de la soberanía mediante el uso de la fuerza. El vocablo revolución remitía al derecho a la resistencia del pueblo frente al despotismo, ya que hacía referencia a la restauración, y no a la ruptura, de un orden originario que había sido pervertido por los gobernantes. Ante el abuso del poder, el pueblo tenía el derecho y la obligación cívicos de hacer uso de la fuerza para restaurar las libertades perdidas y el orden presumiblemente violado por el déspota 5 . Durante la etapa independentista tal principio se había constituido a partir del proceso de dispersión de la soberanía del rey en múltiples soberanías de los pueblos y retroalimentado con contenidos provenientes de las matrices liberal y republicana ${ }^{6}$.

En consecuencia, nacida la República boliviana bajo el signo de la división de la soberanía, los dos ejercicios de la violencia se reconocían como formas legítimas de construcción del orden nacional. Ahora bien, si este podía edificarse a partir del uso de la fuerza concretado en pronunciamientos refundadores o en motines populares avalados constitucionalmente, tales fenómenos también podían atentar contra el orden y estabilidad de Bolivia, poniendo en peligro su crecimiento y consolidación. Ante ello, ¿de qué manera podían conciliarse su gobernabilidad con el derecho y el deber populares a la subversión si la nación se veía amenazada por la tiranía?, ¿cómo obtener un nuevo orden social basado en la soberanía inalienable del pueblo sin que los movimientos sociales deslegitimaran continuamente a las autoridades y sin que éstas se desentendieran de sus demandas una vez conseguido el consentimiento popular?, y, por tanto, ¿de qué manera se podía llevar a cabo el doble proceso de institucionalización del Estado y de la soberanía popular?

Víctor Peralta arguye que los primeros gobernantes bolivianos asentaron la presencia del Estado, combatieron la disgregación territorial y afianzaron el sentimiento de identidad nacional mediante tres medidas gubernamentales: primera, la formulación de una economía política proteccionista, segundo, la activación y resolución de conflictos internacionales, en especial con Perú, y tercera, la pacificación del cuerpo político de la nación a través de los principios de «concordia, fusión y unitarismo» ${ }^{7}$. De las tres medidas, este texto se va a centrar en la tercera, en la relativa a cómo alentar la unión entre el Estado y la sociedad, entendida como la erradicación de las luchas regionales y la competencia partidista fratricida. En la época de los generales Santa Cruz (1829-1839), José Ballivián (1839-1846) y Belzu esos males fueron combati-

\footnotetext{
5 Sábato, LXIX/246 (Madrid 2009): 163.

6 Irurozqui, 2007. Thibaud, 2008: 219.

7 Peralta e Irurozqui, 2000: 33-137.
} 
dos a partir del ideal de «unanimidad, armonía o unidad civil». Éste buscaba la contención de la lucha a muerte entre facciones a través de la reunión de todas las opciones políticas en un partido único. Bajo una concepción simbiótica entre el unanimismo corporativo del antiguo régimen y los principios republicanos de «bien común» y la «voluntad general», se apelaba a él porque a muchos aún les resultaba inconcebible que prevalecieran los intereses particulares y se produjera una división de opiniones contraria a la unión moral del cuerpo político de la nación. Como resultaba impensable que, con independencia del nuevo concepto de libertad, pudieran no existir idénticas opiniones acerca de que el objetivo supremo de todo nacional fuese el bienestar de la nueva república, el partido único se asumió como la sustancia misma del pueblo. Sin embargo, ello no limitó los enfrentamientos partidarios quedando en evidencia que esa fórmula no satisfacía la función de la representación. Por tanto, la pluralidad de intereses que albergaba toda sociedad hizo estallar las visiones unanimistas de la nación y cobró vigencia la heterogeneidad política ${ }^{8}$. Conscientes de que el espíritu faccioso era un elemento imprescindible e inevitable en el sistema representativo democrático ${ }^{9}$ y conforme al ideal republicano que cifraba la de-

8 Rosanvallon, 1998. Schelchkov 2007: 92-108. Ternavasio, 2003: 57-59. Irurozqui, 79/2 (Madrid, 2008).

9 Bajo el principio del «gobierno del pueblo» existen dos sistemas con maneras diferentes de materializar su soberanía: la democracia clásica y la democracia representativa. El primero hace referencia a una forma de vida en la que los ciudadanos participan en el autogobierno y la autorregulación del mismo y no renuncian a la totalidad del poder, sino sólo a aquella porción necesaria para mantener el buen orden. El segundo es una forma de gobierno en la que el pueblo deja de ejercer el poder, aunque sea su fundamento, siendo funcionarios electos a través de comicios periódicos los que asumen la representación de sus intereses y/u opiniones en el marco del imperio de la ley. De ambos sistemas, el que fue establecido constitucionalmente tras la fundación nacional boliviana fue el segundo. Si bien domina el tópico referente a que la representación se eligió por entenderse como una forma política nueva capaz de evitar el «gobierno despótico de masas» cuya irracionalidad ponía en peligro el orden social y económico, en este texto se defiende un argumento ajeno a «discriminaciones de clase». El sistema representativo fue un instrumento técnico cuya finalidad fue asegurar la gobernabilidad de una república fundada tras un proceso bélico de revolución en el mundo hispánico. Éste no sólo había convertido a la Audiencia de Charcas por doce años en un campo de batalla entre distintas fuerzas - autoridades virreinales/poderes locales, realistas peruanos/independentistas bonarenses, constitucionalistas españoles/ absolutistas criollos, guerrillas locales/ejército de línea virreinal—, sino que también había originado una fragmentación de la soberanía y dado lugar a experiencias constitucionales que posibilitaron una ciudadanía universal masculina y una municipalización del poder. Acabado el conflicto, se imponía desmilitarizar a la sociedad y reconducir el proceso de atomización territorial. Un régimen de democracia directa no hubiera sido el más conveniente debido a que su desarrollo habría ahondado la dinámica de fragmentación del poder y de localización de la autoridad a causa de los autogobiernos municipales. De ahí que en la Repu- 
fensa del orden constitucional en la acción política de sus ciudadanos, adquirió importancia el principio de la fusión o de «fraternidad y tolerancia recíproca de partidos». Éste abogaba por la gestión de las disidencias políticas a partir del reconocimiento por parte de las autoridades gubernamentales del derecho de los opositores a expresar públicamente puntos de vista divergentes e incluso un desacuerdo total, siempre y cuando no recurrieran a la fuerza o a alianzas con países extranjeros para imponer su punto de vista político.

Aunque el gobierno de Achá materializó la política de fusión con la formación de un gabinete de gobierno multipartidista con el que buscaba contener posibles insurrecciones, su éxito en implantarla no provino sólo de decisiones ministeriales, sino que requirió la acción del pueblo en armas. Ello implicó que en el contexto de las Matanzas del Loreto hubo un enfrentamiento entre los dos tipos de violencia política expuestos. Si la ejercida por los militares rebeldes puso en peligro la propuesta de fusión de Achá, la violencia protagonizada por el pueblo paceño contra Yáñez y sus seguidores logró lo contrario. No sólo impidió el triunfo de la primera, sino que hizo posible la instauración de la iniciativa de Achá mediante una combinación de violencia revanchista popular con actuaciones asamblearia y asociacionista originadas a partir del municipio y coordinadas desde una junta de gobierno.

Este episodio acerca del modo en que la violencia ayudó a la consolidación del Estado y a la definición de las potestades del pueblo en la concreción del mismo se va a exponer en dos acápites que relacionan la política de fusión de Achá con el ejercicio público de la violencia. El primero se centra en las $M a$ tanzas de Yáñez y la consecuente crisis de legitimidad del gobierno provisional, mientras el segundo abarca la muerte de Yáñez y el resultante asentamiento presidencial de Achá. Con ellos se tratará de responder a tres preguntas: ¿qué relación existió entre abuso de autoridad, legitimidad gubernamental y acción popular?, ¿cómo la movilización popular asentó la política de fusión de Achá? y ¿quiénes y de qué modo capitalizaron la violencia del pueblo?

blica boliviana la soberanía popular se regulara a través de dos fórmulas: por una parte, la delegación del gobierno en un grupo escogido de ciudadanos atentos al interés general que tamizasen la opinión pública; y, de otra, la limitación o moderación del poder político por un conjunto de mecanismos que establecieran los frenos y contrapesos necesarios y recogidos en la Constitución (Irurozqui, 2005: 13-14). 
Primera etapa de la Política de Fusión: las MatanZas de YÁÑEZ

El 14 de enero de 1861 el general Manuel Antonio Sánchez, Ruperto Fernández, ministro de Estado, y José María Achá, ministro de Guerra, lideraron con éxito una sublevación ministerial contra el presidente José María Linares $(1858-60)^{10}$. En el Manifiesto de la Junta Gubernativa a la Nación justificaron el golpe de Estado, calificado de «restaurador del orden legal» y «revolución regeneradora», con argumentos relativos a que la dictadura nacida de la revolución septembrista de 1858 no avanzaba en el desarrollo de sus principios y entorpecía el proceso de democratización del país. Ello sucedía porque «la soberanía y el derecho» se habían supeditado al abuso de la fuerza al no haber realizado el gobierno una asamblea constituyente tras la revolución y, por tanto, haber retardado la redacción de una nueva constitución y la formación de un congreso ${ }^{11}$. Entre el 14 y el 29 de enero de 1861 la Junta decretó la reorganización del personal de las subsecretarías de Estado y la realización de un proceso electoral destinado a seleccionar a los miembros de una asamblea constituyente. Además de encargarse de elaborar un texto constitucional, estos asamblearios serían también los responsables de elegir al presidente provisional de la república entre los tres triunviuros; lo que forzó a éstos a conseguir el mayor número de adeptos. Tal tarea se hizo bajo una exhaustiva supervisión de los trabajos electorales de los rivales, permitiendo la reñida competencia de los candidatos el desarrollo de actividades ligadas a los principios de «libertad de opinión, reunión y asociación» como clubes u otras asociaciones, tertulias públicas en locales comerciales, edición de periódicos y sueltos, y festejos públicos ${ }^{12}$. El objetivo no sólo era evitar posibles abusos de poder, sino sobre todo generar un clima de legitimidad electoral que no pusiese en compromiso

10 Manuel H. Guerra, Memoria de los actos políticos y administrativos de la autoridad departamental durante la gloriosa revolución de septiembre, La Paz, S/L, 1857, Archivo y Biblioteca Nacionales de Bolivia (ABNB). M863/XVI; La Bandera Tricolor, La Paz, 10 de marzo de $1861 ; 15$ de marzo de 1861.

11 José María de Achá, Mi defensa, La Paz, Imp. Del Vapor, 1861: 1-9. Mensaje de la Exma. Junta de Gobierno a la Asamblea Nacional de 1861, La Paz, Imp. Del Vapor, 1861: 4, ABNB. 872. La Bandera Tricolor, La Paz, 11 de abril de 1861; 27 de abril de 1861; 6 de mayo de 1861. Rodríguez, 1995: 39.

12 El Club Septembrista, Sucre, Imp. Boliviana, 1861; Satisfacción. Sucre, Imp. Boliviana 1861; Acta del Club Patriótico-Septembrista, Sucre, Imp. Boliviana, 1861; Dirán que la fuerza triunfa sobre ellos, Sucre, Imp. Boliviana, 1861; Hoja electoral del Club Patriótico-Nacional, Sucre, Imp. Boliviana, 1861; Agustín Morales, A los pueblos del Sud, Potosí, 21 de abril de 1861; Benedicto Trifón Medinaceli, Mi candidatura y mi programa para la Convención Nacional, Sucre, Imp. De Beeche Arrendada, 186: 1; «Club de La Concordia», La Concordia, Oruro, 16 de de marzo de 1861, ABNB. M798/K. 
la victoria frente a Linares, más cuando el golpe de Estado no había implicado una movilización popular. El resultado de la elección fue una asamblea multipartidista en la que había diputados «de toda condición» ${ }^{13}$. La Asamblea se instaló el 1 de mayo de 1861 en la antigua capilla del Loreto, ahora salón universitario y recinto legislativo, y estuvo presidida por Adolfo Ballivián. Tras declararse constituyente delegó el poder político a la Junta de Gobierno hasta que se tomase una decisión sobre el gobierno provisorio. Ésta se produjo el 4 de mayo, siendo nombrado Achá presidente por 820 votos contra 16 y ratificado como tal el 6 de agosto de 1861 bajo el compromiso de respetar la alternabilidad en el poder mediante la convocatoria de elecciones libres ${ }^{14}$. Asimismo, de acuerdo con los propósitos de la concordia referentes a olvido de los pasados agravios y legalidad en los procedimientos, aceptó tanto la amnistía general de los bolivianos o extranjeros acusados de delitos o causas políticas, como la cancelación de los procesos judiciales al respecto, decretadas por la Asamblea. Ésta se clausuró el 15 de agosto ${ }^{15}$.

Aunque la elección de Achá no fue cuestionada por los otros dos miembros de la ex junta gubernativa, éstos, en especial Ruperto Fernández, nuevo ministro de Estado y Justicia, se mostraron decepcionados y críticos ante el hecho de que el presidente quisiese desarrollar una política de fusión contraria a la hegemonía en el gobierno de los septembristas ${ }^{16}$. Su gesto conciliador, además de juzgarse en exceso condescendiente con los belcistas y responsable de poner en peligro la causa de septiembre, se interpretó también encaminado a la formación de un partido personal propio ${ }^{17}$. Conforme a los principios de la fusión de evitar los «banderios exclusivistas» o «el espíritu de partido» que provocaban el exterminio del bando rival y de lograr el «bienestar común por medio de la tolerancia en política y la moderación en el gobierno», Achá intentó combatir el monopolio partidista del poder y, con ello, pacificar el escenario político, mediante la inclusión en su gabinete de gobierno de conocidos belcistas como Rafael Bustillos. Esa decisión resumía la necesidad de crédito públi-

13 Linaristas exaltados como Tomás Frías, Evaristo Valle, Mariano Baptista y Adolfo Ballivián; septembristas como Agustín Morales, Natalio Irigoyen, Genaro Palazuelos, Sebastián Cainzo, Miguel Rivas, Fermín Barrero, José Emilio Iturri, Manuel María Vicenio o Bernardino Sanjinés; belcistas como Rafael Bustillo; cordovistas como Emeterio Valle Villamil; e independientes como Agustín Aspiazu, Macedonio Salinas, Aniceto Arce, Manuel José Cortés o Antonio Quijarro.

14 Poder Legislativo, núms. 186 y 187, ABNB.

15 Arguedas, 1959: 726-759. La Bandera Tricolor, La Paz, 6 de mayo de 1864.

16 Ruperto Fernández, Mi defensa, Salta, 13 de enero de 1862, en Ligera exposición de los últimos acontecimientos de Bolivia. Potosí, Imp. Republicana, 1861: 5-7, ABNB. Bd 959.

17 René-Moreno, 157-58, 183. 
co que tenía un gobierno nacido de una revolución que había puesto en peligro el «equilibrio social». Sólo podía «suplir el desprestigio de origen independiente» y ser respetado si daba pruebas de la importancia de sus servicios a la nación. Y ello, además de implicar la utilización de la constitución como una garantía del ejercicio popular de la soberanía y no como un arma, se materializaba en la voluntad de gestionar las rivalidades partidarias en el ámbito exclusivamente político para atenuar uno de los males que afectaban el buen gobierno del país: la militarización de la política o el «militarismo pretoriano» ${ }^{18}$.

Como ya se indicado, bajo el principio de unanimidad el consenso entre partidos fue entendido como la homogeneización del pensamiento político sostenido por los mismos. Su obtención no resultaba tan problemática como la regulación de la sucesión en el poder en un contexto de partido único ${ }^{19}$. Dado que éste era inviable bajo un régimen democrático representativo en el que el conflicto entre facciones expresaba la diversidad de la voluntad popular, la tradicional combinación revolución-elecciones o golpe de Estado-elecciones encontró en la política de la fusión el medio de lograr un acuerdo entre partidos que desterrara la obligatoriedad del componente de violencia y asegurara el gobierno mediante la corrección de dos males: «las resistencias del partido vencido y el principio de autoridad victorioso que ninguna concesión quería hacer a los hombres del pasado». Esto es, ya que la opinión del pueblo no podía uniformarse, las soluciones del partido único y del «gobierno de partido» se sustituían por la de un partido nacional. Éste provendría de una facción que una vez alcanzada la presidencia estaría obligada a incorporar a la oposición en el ejercicio del poder para que el gobierno pudiera ejercer de intérprete de la soberanía del pueblo. Ello tornaba al patriota en «el amante de la paz y de las instituciones», siendo el golpismo un recurso político a erradicar ya que al basarse en «la inobservancia de las constituciones» apagaba «el genio revolucionario y democrático $»^{20}$. Sin embargo, como ilustra la experiencia de Achá, esto no fue tan fácil de conseguir. El asentamiento de la política de fusión fue resultado del ejercicio popular de la violencia desencadenada precisamente por la aplicación del principio de «muerte al partido opositor» ejemplificada en la Matanza de Yáñez. Es decir, paradójicamente la militarización de la política se corrigió mediante un levantamiento armado de la población paceña

18 Mensaje de la Exma. Junta de Gobierno a la Asamblea Nacional de 1861, La Paz, Imp. Del Vapor, 1861: 2-4, ABNB. 872. Villamil, 1858: 11-19.

19 Irurozqui y Peralta, 42 (México, 1998): 147-176.

20 Mensaje de la Exma. Junta de Gobierno a la Asamblea Nacional de 1861, La Paz, Imp. Del Vapor, 1861: 4-8, ABNB. 872. La Bandera Tricolor, La Paz, 2 de abril de 1861; La Concordia, Oruro, 8 de marzo de 1861. 
que no secundó una revolución militar, quedando la figura del ciudadano en armas en un ámbito exclusivamente civil. Veamos ahora el desarrollo de ese episodio.

Como presidente provisional, Achá debía resolver dos asuntos inmediatos, uno de orden interno y otro de orden externo. Mientras el primero se refería a las sublevaciones facciosas, el segundo informaba del peligro de una invasión peruana para una anexión parcial del territorio boliviano. Ambos asuntos exigían una resolución común en la medida en que la acción invasora extranjera había estado en ocasiones anteriores coordinada con los partidos desalojados del poder. Al respecto, el caso de la conspiración del argentino Dalmiro A. Cordero $^{21}$ alertó de que podía haber belcistas involucrados en la agregación del departamento de La Paz al Perú. Muchos septembristas creyeron verlo confirmado en el hecho de que tras la amnistía miembros de la administración de Belzu y de Córdova habían regresado al país y, en especial, a La Paz. Al clima de rumores de conspiraciones y motines, se sumó que Achá era visto con suspicacia por parte de sus correligionarios. Con el triple propósito de desbaratar posibles exhibiciones de fuerza contra su gobierno, de asentar su autoridad dentro de su partido y afianzar su presencia nacional, el mandatario decidió dejar La Paz y recorrer el país.

Achá encomendó al coronel Plácido Yáñez, Comandante General de Armas, el mantenimiento del orden público en la ciudad de La Paz, pidiéndole que prestara especial atención a los movimientos de los belcistas y a posibles tramas anexionistas peruanas. En respuesta a esa indicación, a finales del mes de septiembre comenzaron a ser arrestados ex miembros de los gobiernos belcistas, altos cargos del ejército ya retirados, algunos abogados, oficiales en servicio activo y soldados. Se les acusaba de tramar un motín belcista apoyados por «el populacho» y algunos soldados de la columna municipal ${ }^{22}$. Tal sublevación debería tener lugar el 30 de septiembre con ocasión del ejercicio de «armas y guerrilla» que debía hacer dicho cuerpo. Es decir, se trataba de una sublevación desenmascarada «antes de estallar», lo que significaba que ninguno de los detenidos había sido descubierto en flagrante delito. Informado el gobierno en Potosí de lo sucedido, el 5 de octubre dispuso que todos los detenidos, militares y paisanos, fuesen juzgados por un consejo ordinario de guerra y decretó el estado de sitio en las provincias de Pacajes e Ingavi y en el distrito de $\mathrm{La} \mathrm{Paz}^{23}$. En un contexto en el que los rumores de sedición iban en aumento, las medidas cautelares tomadas por Yáñez recibieron respuestas

\footnotetext{
21 Sotomayor, 1874: 203-204.

22 El Alacita, 1862: 1-2.

23 Sotomayor, 1874: 209; René-Moreno, 1954: 26-27.
} 
contradictorias por parte de la población. Por un lado, estaban quienes aplaudían y alentaban el celo demostrado por el militar para evitar una nueva revolución ${ }^{24}$; por otro, quienes no sólo consideraban extremas las medidas contra los belcistas, sino contrarias a la ley ${ }^{25}$, siendo al principio mayoría los primeros. Frente a ello, en su papel de «sostenedor del orden público», Yáñez persistió en su conducta de encarcelar a todos los belcistas de La Paz, incluido el ex presidente Jorge Córdova. Tras un intento fallido de demostrar que en su quinta de San Jorge éste hacía reuniones conspiradoras y acopio de armas, fue apresado el 21 de octubre debido a una nueva denuncia hecha por un sargento segundo y un soldado de la columna municipal que le acusaban de haberles abordado en la pulpería del barrio de Huturunco y pagado para que le ayudasen a liberar a los prisioneros. Se le recluyó en el Loreto junto a los principales prisioneros políticos ${ }^{26}$.

Los acontecimientos que dieron lugar a la Matanza del Loreto tuvieron lugar la noche del 23 de octubre. En la versión defendida por Yáñez ${ }^{27}$, éste dijo que se había despertado al oír «un tiro en el cuartel del batallón Segundo situado a pocas calles del palacio de gobierno». Su alarma quedó confirmada por el bullicio procedente de la plaza y por el hecho de que cuando él y su hijo Darío se asomaron a los balcones recibieron descargas de arma. Tras llamar al coronel Luis Sánchez para que sostuviese el fuego con seis rifleros y dos fusileros, Yáñez salió con la columna municipal - unos cien hombres - a la plaza. Ésta fue dividida en dos secciones. De una se hizo cargo el oficial Benavente con el cometido de atacar al grupo que les disparaba, mientras la otra con Yáñez al mando, tras defender los otros lados de la plaza, se dirigió al Loreto. Una vez allí preguntó al custodio del lugar, el capitán Rivas, por las novedades acaecidas y éste le contestó que ninguna, salvo que Córdova había intentado dos veces atropellar al oficial de guardia Núñez. En respuesta Yáñez dio la orden de «pegarle cuatro tiros», acción que cumplió el oficial Leandro Fernández. Después de indicar a Fernández y al oficial Cárdenas que ejecutaran a los deteni-

\footnotetext{
24 Gacetas como El Telégrafo y El Boliviano ahondaban en la atmósfera de desconfianza y recelos contra los belcistas.

25 Carvajal, 1864: 1-22; Carta de Saturnino Sanginés, fiscal del distrito, a Rudesindo Carvajal, La Paz, 16 de diciembre de 1861, ABNB. M412.

26 El Boliviano, La Paz, 2 de noviembre de 1861.

27 «Cartas y documentos oficiales referentes al 23 de octubre», El Constitucional, La Paz, 25 de mayo de 1862. Al respecto véanse la cartas escritas por Yáñez a Achá del 30 de septiembre, del 4, 20 y 24 de octubre, del 3, 12 y 20 de noviembre de 1861 en las que Yáñez expone su celo en el control de los belcistas y en las que se advierte su progresiva angustia y desesperación ante el hecho de que su defensa del orden no sólo no es comprendida por Achá, sino que posiblemente va a ser castigado por ello.
} 
dos en el cuartel del batallón Segundo, Yáñez hizo salir a todos los presos del Loreto de cuatro en cuatro. A excepción del general Calixto Ascarrunz, por el que intercedió Darío, todos fueron muertos. A ellos les siguieron los presos encarcelados en el cuartel de policía y en la cárcel, ocurriendo la matanza a mayor escala en el cuartel del batallón Segundo. Allí el único superviviente fue Demetrio Urdininea, del que se supo más tarde que era un espía de Yáñez ${ }^{28}$.

¿Cómo reaccionó el gobierno cuando conoció lo sucedido? Achá recibió la noticia en la ciudad de Sucre a través del ministro Fernández, quien interpretó muy favorable para los septembristas la casi desaparición de los principales miembros del partido de Belzu. La actitud victoriosa de muchos de ellos no sólo obligó al ministro Bustillos a renunciar a su cargo, sino que también debilitaba políticamente a Achá ya que mostraba fracasada la política de fusión a causa de la irredente actitud conspiradora de los belcistas. Bajo el entendimiento de que con lo ocurrido se había abortado una revolución y salvado el orden público, las cartas que el presidente envió en un inicio a Yáñez no lo reprobaron, sino que parecían aceptar que las autoridades escarmentasen a los belcistas por el miedo a una conspiración ${ }^{29}$. Si bien ello fue más tarde utilizado para imputar a Achá la responsabilidad de los hechos, es necesario precisar que las primeras informaciones oficiales remitidas justificaban lo sucedido, sin que personajes críticos con Yáñez como el jefe político Rudesindo Carvajal expresase aún el horror que le producían sus actos. También hay que tener en cuenta que en esos momentos Achá se encontraba en una situación delicada debido al comportamiento hostil de Fernández y al favor que recibía de los linaristas. Y aunque el ministro no contaba con el apoyo de sus correligionarios de gabinete, cuyos miembros consideraban que hacía un uso privado de los recursos gubernamentales, Achá había desatendido sus peticiones de creación de un nuevo equipo de gobierno que lo excluyera porque temía que con ello precipitase un nuevo golpe de Estado. De hecho, como demostración de su poder, Fernández había colocado al ejército bajo las órdenes de jefes que le eran adictos, los coroneles Nicanor Flores y Nicanor Balza. En contrapartida, Achá sólo tenía la lealtad de la columna de rifleros que montaban la guardia de palacio. En esa situación de indefensión, la recriminación pública de la actuación de Yáñez, que era su valedor en La Paz, podría forzarle a aliarse con Fernández.

28 Sotomayor, 1874: 212-216; Arguedas, 1959: 767-772. Sobre la invención de un complot revolucionario y de Urdininea véase también Romero, 5 (La Paz, 1995): 171.

29 Ruperto Fernández, Mi defensa, Salta, 13 de enero de 1862: 2-4, ABNB. Bd. 959. Julio Méndez, «Carta a Yáñez», El Constitucional, La Paz, 12 de mayo de 1862; «Cartas y documentos oficiales referentes al 23 de octubre», El Constitucional, 25 de mayo de 1862. 
Si bien los primeros días tras la ejecución de los presos belcistas, las autoridades y la población estuvieron aturdidos, poco a poco el pueblo de La Paz hizo responsable a Yáñez de lo sucedido, no quedando claro si era él y sus colaboradores los únicos responsables o estaban involucrados miembros del gobierno, e incluso el presidente. De hecho, la prensa de la época, recogida en la obra de Gabriel René-Moreno, debatió por largo tiempo y con tintes partidistas distintas hipótesis acerca de la Matanza del Loreto: ¿fue una empresa madurada y preconcebida sólo por Yáñez?, ¿se trató de un trabajo alentado por septembristas extremos como Ruperto Fernández que sirviéndose de su celo antibelcista se había aliado con él o le había utilizado para eliminar de manera definitiva al partido opositor? o ¿resultó de circunstancias e incidentes fatalmente combinados? Por ello se consideró necesario dilucidar si había habido una verdadera provocación por parte de las víctimas. En un clima de exacerbación partidista armada en el que cualquier gesto sospechoso se juzgaba como sedición, no se dudaba de que los belcistas pudieran dedicarse a conspirar y a aprovechar cualquier oportunidad para desestabilizar al gobierno ${ }^{30}$. Otra cuestión era que existiera un complot organizado. Muchos de los encarcelados estaban siendo juzgados por su tentativa de seducción de la columna municipal, pero como su acción subversiva se había descubierto antes de materializarse no quedaba clara la veracidad de la misma, habiéndose llegado a infiltrar para probarla a «espías entre los presos para sonsacarles información ${ }^{31}$. Y si ese suceso era dudoso, mucho más lo era que los belcistas hubieran organizado un movimiento de fuga el día 23. A juzgar por los contradictorios testimonios posteriores, parece cierto que sí hubo un tiroteo. Su origen, alcance e intención no estaban claros, siendo confusas las referencias a un intento de movilización de artesanos para dar vivas a Belzu y Córdoba, a disparos de fúsil y al destacamento de tres compañías del cuartel de la Recoba de Sucre en las calles adyacentes a la plaza ${ }^{32}$. Ahora bien, sí el ataque fue fingido, ¿quiénes fueron los responsables?, ¿lo organizó Yáñez para justificar una posterior represión belcista? o ¿Yáñez fue víctima de una trampa urdida por los hombres de Fernández y otros septembristas para inflamar su encono contra el belcismo y dar salida a su natural ferocidad? ${ }^{33}$

30 Apuntes para la historia de Bolivia. Bolivia desde la noche de 25 de noviembre hasta enero de 1861, ABNB BO Ruck 415.

31 Sotomayor, 1874: 199-216.

32 «Carta de José Santibáñez desde Tacna a Gabriel René-Moreno», René-Moreno, 1954: 47.

33 Linares dijo de Yáñez: «incorregible en su dureza con los oficiales y en su arbitrariedad de dar de baja por sí a los mismos oficiales y eso hizo que lo retirara de su cuerpo, aunque fuese recompensado su honradez, lealtad y patriotismo con la comandancia general de Cochabamba», Memoria sobre algunos hechos, Sucre, 10 de abril de 1861. 
Pese a su atractivo, no es el objeto de este artículo resolver los enigmas planteados por la prensa y René-Moreno, sino reflexionar sobre la acción popular que desencadenó la ejecución de los belcistas. Si los días posteriores a lo ocurrido, los vecinos no estaban de acuerdo acerca de si hubo provocación o conato sedicioso, pasadas tres semanas se inclinaban a que la autoridad había simulado el ataque. De hecho, a medida que el comportamiento de Yáñez se hacía más intolerable para los paceños, el periódico que apoyaba sus medidas de orden, El Boliviano, en respuesta a la propaganda belcista de $E l$ Pueblo, publicó una serie de artículos que justificaban los actos represivos por la conversión de la población en un colectivo que ejercía violencia en las calles seducido por «los banderíos». Sobre ella se escribía que tras perpetrar barbaridades y «crímenes atroces» volvía «a su casa» y con alborozo decía «a su familia: los tiranos que habían proyectado empobrecernos haciendo más enorme las carga de las contribuciones han sucumbido». Tales eran el comportamiento y la naturaleza de «los soldados y los cholos cabecillas de la plebe» que murieron la noche del 23 de octubre, un pueblo ignorante e inmoral, degradado por el faccionalismo y, por tanto, deshabituado al trabajo, que se sublevaba «sediento de sangre y ansioso de rapiña» por culpa de las seducción política. Los belcistas con sus continuos planes de conspiración estaban evitando que la plebe, en vez de ser útil a la sociedad en calidad de «artesanos, fabricantes o agricultores», saliera de «la esfera donde la naturaleza la ha[bía] colocado» y sólo generase caos. En esas condiciones la política de fusión de Achá era una quimera tanto porque el pueblo se había transformado en populacho merced a ser conducido «al terreno de las cuestiones políticas», como porque los belcistas traicionaban los esfuerzos de conciliación del presidente aprovechándose de «un pueblo inmaduro y una tropa desmoralizada ${ }^{34}$. Sin embargo este discurso de deslegitimación de la sociedad en términos de clase y a favor de la desmovilización política de la misma en virtud de su irracionalidad no acalló el descontento. Al contrario, cierta o no la responsabilidad de Yáñez en la organización del ataque, se creyó en ella y eso alentó la cólera popular. No se olvide que además de belcistas notables, había muerto mucha gente de tropa perteneciente a los sectores populares de La Paz. Si a eso se sumaba que todavía continuaban muchos encarcelados por cuya vida se temía ante la actitud homicida de Yáñez y la aparente pasividad de otras autoridades de la ciudad y del gobierno, no era de extrañar una movilización popular «salvadora y justiciera» ${ }^{35}$.

34 El Boliviano, La Paz, 2, 13, 20 de noviembre de 1861.

35 Ibidem, La Paz, 2, 13 y 16 de noviembre de 1861. Artículos pro-Yáñez que avisan de las terribles consecuencias de lanzar a la plebe al teatro de las cuestiones políticas. 
Del lado belcista, ésta pudo estar azuzada por los folletos y la prensa publicados en Lima, Tacna e Iquique que mediante interpelaciones a cuerpos o personas determinados (obispo, artesanos, magistrados, o autoridades municipales) les conminaban a un esfuerzo moral y combinado tendente a buscar un desagravio contra Yáñez ${ }^{36}$. A esa acción propagandística en la que también se vieron involucrados periódicos paceños, se unían las gestiones hechas por las familias de Eyzaguirre, Mendizábal, Guachilla, Saravia y Sardón que se organizaron para ver a los presos después de la matanza y para asistir a las viudas y huérfanos de los caídos. Tales medidas estarían en consonancia con la activación de los lazos de clientela y compadrazgo mantenidos por los belcistas con la población ${ }^{37}$. Del lado gubernamental hay que señalar que cada vez eran más las denuncias sobre la inconstitucionalidad de los actos de Yáñez ${ }^{38}$, las declaraciones acerca de que el gobierno podía perder su apoyo multipartidario, corriendo el riesgo de no ser reconocido como «legítimo, popular y constitucional» si permitía que la voluntad general quedara mancillada por la acción de Yáñez ${ }^{39}$, y las peticiones de que éste fuera juzgado por el bien del septembrismo y del gobierno. Es decir, poco a poco el miedo ante las posibles represalias de Yáñez pudo haber dado lugar a la planificación de un acto de liberación de

36 René-Moreno, 1954: 137-145. «Quosque Tandem abuteris patientia nostra?». Tacna, Imp. Pedro Freire, 1861; La América de Tacna 11 de noviembre de 1861, ABNB BO RUCK 415. El Mercurio de Tarapacá. Iquique, 9 de diciembre de 1861; 16 de noviembre de 1861: 2-4, ABNB, M837. ¡Septembristas adelante!, Tacna, Imp. Andrés Freire, 1861; ;Adelante septembristas!, Tacna, Imp. Andrés Freire, 1861; Delenda Cartago, Tacna, Imp. Andrés Freire, 1861: 1-2; Pedro Lozano, Un tributo de la amistad, Cochabamba, Tip. de Quevedo, 1861: 1-2; Una lágrima sobre la tumba, Tacna, Imp. Andrés Freire, 1861; Bolivia, Tacna, Tip. de «El Porvenir», 1861; El presidente Achá, Tacna, Tip. de «El Porvenir», 1861, ABNB. M794.

37 Calderón, 1993; 2 (La Paz 1996). Richard, 1997. Schelchkov, 2007: 183-197, 212-240.

38 En un papel suelto en Cochabamba el jurista Pablo Barrientos decía que el art. 7 de la Constitución de 1861 abolía la pena de muerte excepto en los casos de asesinato, parricidio y traición a la patria, entendiéndose por traición la complicidad con enemigos externos en caso de guerra. Por tanto, Yáñez al ejecutar a ciudadanos en prisión por sí y ante sí había agravado su enorme crimen en tres circunstancias: 1) por haberse consumado contra una prescripción expresa de la Constitución; 2) por las formas horrorosamente sumarias de la ejecución; y 3) por el número de víctimas. En su opinión, ello quedaba reforzado por el art. 11 que indicaba que, en caso de conmoción interior que pusiese en peligro la Constitución o las autoridades creadas por ella, se declararía en estado de sitio el departamento o provincia donde existiese la perturbación del orden, quedando allí suspendidas las garantías constitucionales. Durante esta suspensión el poder ejecutivo se limitaría con respecto a las personas a arrestarlas o a trasladarlas del punto sitiado a otro de la nación, no estando bajo ningún pretexto permitido emplear el tormento ni otro género de mortificación» (René-Moreno, 1954: 68-69).

39 iCrimen atroz! Contra la Constitución. Cochabamba, Tipografía de Los Amigos, 9 de noviembre de 1861, ABNB. M794/III; El Pueblo, Sucre, 20 de noviembre de 1861: 4, ABNB, M833. 
los presos que se tornó más tarde en venganza homicida, siendo el motín de Balza una ocasión perfecta para alentar y justificar el ejercicio de la violencia «en nombre de la conservación del orden y del régimen constitucional» ${ }^{40}$. Veámoslo en el siguiente apartado.

\section{Segunda etapa de la Política de Fusión: MUerte de YÁÑEZ}

Achá aprovechó su viaje de regreso a La Paz para asentar poco a poco su autoridad mediante la distribución de cargos militares entre sus hombres de confianza. El 15 de noviembre, a tres días de Oruro, en la localidad de Pocoata concedió licencia al coronel Flores y le separó del mando del batallón Primero. En su lugar nombró al coronel Mariano Melgarejo, quien logró que los soldados se plegaran a su jefatura. Asimismo, otro opositor, el coronel Morales, se vio obligado a abandonar su cargo de Jefe Superior del Ejército del Sur para ocupar el de Comandante de Armas del departamento de Sucre, en cuya capital sólo se dejó una columna municipal de 150 hombres. En Chayanta, el 17 de noviembre Achá mandó una comisión rápida a Oruro con el ministro de Guerra, el general Celedonio Ávila, a fin de separar al coronel Balza, jefe superior político y militar del Norte, de la dirección del batallón Tercero, del escuadrón Húsares y de una sección volante de artillería. El control de esas fuerzas debía recaer en Yáñez, siéndole dada a Balza la comandancia general de $\mathrm{La} \mathrm{Paz}^{41}$. La misión no tuvo éxito porque éste se había dirigido a La Paz sin permiso del presidente y bajo instrucciones secretas de Fernández, quien consciente que lo sucedido con Yáñez no había disuadido al gobierno de su política fusionista, había decidido sustituir a Achá42 ${ }^{2}$ En consecuencia, Ávila marchó a esta ciudad para cumplir allí su cometido y tomar medidas humanitarias a favor de los belcistas que aún seguían presos. Hasta ese momento el coronel José María Cortés, ausente de la ciudad el día de las ejecuciones, había actuado de contención de los excesos de Yáñez. Aunque no había liberado a los cautivos por considerar que la autoridad de éste aún no había sido cuestionada por el gobierno, su presencia impedía iniciar nuevos ajusticiamientos. El clima de miedo y descontento que dominaba la ciudad hizo que Ávila, en connivencia con las autoridades municipales y el vecindario, optara por la liberación de los encarcela-

40 El Constitucional, La Paz, 2 de diciembre de 1861.

41 René-Moreno, 1954: 83-84.

42 Carta de Ruperto Fernández a José María de Achá, Sucre, 27 de noviembre de 1861: 12; Carta de Ruperto Fernández al teniente coronel Eduardo Dávila, Sucre, 21 de noviembre de 1861: 11-12, ABNB. Bd 959. 
dos el 21 de noviembre, sin que ello generase un enfrentamiento con Yáñez, a quien cada vez le iba quedando más claro que su celo contra el belcismo no iba a recibir los parabienes esperados.

Pero si Ávila tuvo éxito con Yáñez, no fue así con Balza que rechazó sus órdenes. El 23 de noviembre con el batallón Tercero se apoderó del cuartel de la columna municipal y destinó tres compañías dirigidas por el teniente coronel Federico Tardió a tomar el batallón Segundo. Éste estaba bajo el mando de Cortés que resultó muerto en el enfrentamiento. El resultado de la batalla fue confuso porque, aunque Balza obligó a las fuerzas del gobierno a retirarse a Calamarca, la «espontánea» participación armada del pueblo paceño con el objetivo de ajusticiar a Yáñez y a sus secuaces impidió que pudieran capitalizar su victoria. La prensa de la época describió al pueblo como «la cholada» que llegaba al lugar del combate «en grandes pelotones pidiendo la cabeza de Yáñez». Ante la insistente pregunta popular de «¿Y Yáñez?, ¿dónde está Yáñez?», Balza, para impedir que sus fuerzas fueran consideradas cómplices de éste y desviar su ferocidad hacia el enemigo, declaró que se encontraba con el batallón Segundo en el cuartel donde se defendían los partidarios del gobierno. Eso explicaría por qué «la plebe» actuó en un inicio en unión con los sublevados, abandonándolos más tarde cuando descubrió que su perseguido no combatía en ningún bando, sino que se hallaba en la Caja, edificio colonial situado en el ángulo sudeste de la plaza mayor, con unos cuarenta rifleros escogidos. Allí Yáñez mantenía una postura expectante ante los enfrentamientos armados. Ello podía interpretarse como resultado de una alianza secreta con Balza, ya que a éste no le convenía su apoyo explícito debido a «lo odioso que se había hecho al pueblo», o de su convencimiento de que Achá no iba a premiar su conducta, siendo sin duda alguna Fernández mucho más comprensivo por su compartido repudio de los belcistas ${ }^{43}$. Así, en un contexto en el que nadie se aclaraba a favor de quién estaba Yáñez, «si del orden o de Balza», «la masa popular compacta, sedienta, inmensa y soberana» fue tras él con el objetivo de castigarle. Cuando Yáñez fue consciente de la muchedumbre que le perseguía se encerró con unos pocos rifleros esperando el auxilio de la columna municipal situada en el cuartel de Santa Bárbara ${ }^{44}$. Como ésta no llegaba trato de huir a través de los tejados. Allí fue descubierto y tras recibir varios disparos cayó

43 Carta de Ruperto Fernández a Plácido Yáñez, Potosí, 6 de octubre de 1861; Sucre, 4 de noviembre de 1861, ABNB, Bd. 959. «Cartas y documentos oficiales referentes al 23 de octubre», El Constitucional, La Paz, 25 de mayo de 1862.

44 René-Moreno, 1954: 185-190. Mensaje del Presidente provisorio de la República Boliviana a la primera Asamblea Constitucional reunida en la capital de Sucre en 1862, Cochabamba, Tipografía de Gutiérrez, 1862: 5, ABNB, M 872. 
al patio de una vivienda contigua. A ella entró una multitud que se ensañó cruelmente con su cadáver ${ }^{45}$. Después lo arrastró al Loreto y luego al Cenizal, convirtiéndose los escenarios de los ajusticiamientos ordenados un mes antes por Yáñez en un irónico recordatorio acerca de que éste había muerto por adherirse al principio de orden de una manera extrema y por proclamar la paz pública a través de una violencia desmesurada contra la oposición que no fue recibida por la población como legítima.

Pese a su victoria militar, la situación de los sublevados era incierta. El pueblo movilizado para ejecutar a Yáñez no había hecho causa con los amotinados y, por tanto, no era «un pueblo armado que apoyaba las revoluciones». Ello implicaba que en cualquier momento podían volver a alzarse por el bien público y esta vez contra ellos. Ante esa presión, Balza intentó desarmar a la población de dos modos. Por un lado, buscó eliminar cualquier sospecha relativa a que su sublevación había contado con el apoyo o el conocimiento del ajusticiado Yáñez. Éste había perdido su legitimidad en el mando por ejercer un abuso de autoridad, justificándose entonces una movilización y linchamiento populares. De ahí que lo injuriase públicamente en un discurso hecho a los granaderos del batallón Tercero:

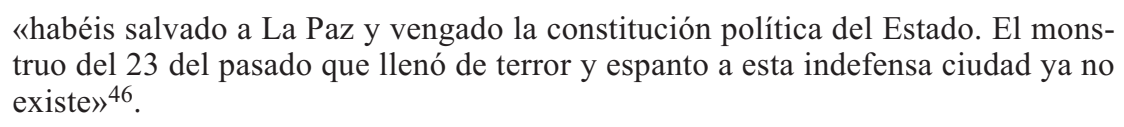
truo del 23 del pasado que llenó de terror y espanto a esta indefensa ciudad ya no existe» ${ }^{46}$.

Sin embargo, esas palabras estaban en contradicción con el hecho de que nunca, desde su llegada a La Paz, había pretendido aprehender a Yáñez ni liberar a los cautivos, algo que sí habían hecho las fuerzas gubernamentales. Por otro lado, forzó al municipio a canalizar «ordenadamente» la voz del pueblo para que la población que había hecho frente a los excesos de Yáñez quedase supeditada a los dictados de un grupo de notables que no habían sabido o querido frenarlo. Con esa pacificación controladora de la fuerza del pueblo sublevado no sólo quería suprimir la amenaza a su victoria representada por los «torrentes de plebe encabezada por grupos considerables de cholos armados». También pretendía asentar su triunfo militar con el apoyo del poder civil de la ciudad $^{47}$. Con ese objetivo Balza se dirigió al presidente de la municipalidad y,

45 El comisario Leopoldo Dávila fue ejecutado en la calle de la Caja, siendo también buscados el comisario primero, Manuel Monje, y el fiscal Pedro Cueto.

46 Proclama del Jefe Superior Politico y Militar del Norte a las fuerzas de su mando, La Paz, 24 de noviembre de 1861, ABNB. Bd. 959.

47 Según René-Moreno, el hecho de que «el populacho justiciero» se retirara sin querer plegarse a la rebelión militar de Balza hizo que su socio, el ministro Fernández, explicase el rechazo a sus actos por la corrupción del pueblo y, por tanto, reiterara el binomio populacho/pue- 
según El Constitucional, se presentó como «un ciudadano armado» en el que el pueblo había depositado sus garantías. Como ya creía cumplido el deber de salvaguardarle de la tiranía invitaba «al respetable pueblo» a concurrir el mismo día 23, a las cinco de la tarde, en el salón de la universidad, «a nombrar las autoridades que deben mantener el orden en el país y garantizar la propiedad $»^{48}$. Aunque su iniciativa fue aceptada, los asistentes, «patricios y una numerosa barra popular» dejaron claro que ello no comportaba ningún compromiso político con Balza. Se habían reunido para cautelar «la tranquilidad política y la propiedad» ante posibles desmanes del pueblo movilizado. Se acordó celebrar al día siguiente una junta, a la que acudió el segundo de Balza, el coronel Tardío. El deseo de los sublevados era que los miembros de la junta presidida por Diego Monroy admitieran que había sucedido un cambio político. Sin embargo, concluyeron lo contrario: ya estaba establecido legalmente un gobierno nacional, de manera que si los reunidos realizaban nombramientos entre los sublevados cometían un grave delito contra la Constitución. En consecuencia, se ratificaron a las autoridades legales existentes antes de lo sucedido el 23 de noviembre, como era el caso del jefe político Carvajal ${ }^{49}$, y se decidió que el general Gregorio Pérez, un «hombre de orden, siempre del orden y de las instituciones», ocupase provisionalmente el puesto ocupado por Yáñez ${ }^{50}$.

En definitiva, la junta de gobierno celebrada el 24 de noviembre en el Loreto no supuso el reconocimiento del triunfo de los rebeldes. Al contrario, los discursos pronunciados por los asistentes «para llamar al pueblo a las vías del buen sentido y del orden», sólo desacreditaron el motín militar ${ }^{51}$. Esto es, la iniciativa de Balza de que fueran las autoridades civiles y los vecinos notables los que apaciguasen la acción popular tuvo como resultado que éstos tomasen el control de la ciudad y organizasen mediante fórmulas asociacionistas no tanto la pacificación del pueblo, sino la rendición pacífica

blo decente, siendo posible la regeneración del primero a través de una política de orden por parte del segundo: «pero el pueblo, el verdadero pueblo, ¿en pos de qué va? Va como toda asociación de hombres cultos o bárbaros en pos del progreso. ¿Y quién aleja y oscurece ese porvenir? Los bandos que cada día reciben y dan de alta en sus filas a gente mala, así como disminuyen cada día en esas filas las plazas del honrado, del industrial, del progresista, del hombre bueno». René-Moreno, 1954: 11.

48 Ibidem: 151 y 204-216.

49 Rudesindo Carvajal, Breve exposición de mis circunstancias públicas y privadas como Jefe Político de la ciudad de La Paz en el último trimestre de 1861, Sucre, Tip. Pedro España, 1864: 14, ABNB. M412.

50 René-Moreno, 1954: 216-218.

51 Sotomayor, 1874: 227. 
de Balza y sus soldados al gobierno. La violencia militarista quedaba, así, acallada por la violencia popular reconducida institucionalmente por los vecinos de La Paz. Éstos redescubrían el antiguo principio de la legitimación de la rebelión del pueblo contra el gobernante tirano, reasumían sus poderes e iniciaban un proceso de delegación de los mismos a través de una junta.

El general Pérez asumió el mando militar provisional de la ciudad en espera de la llegada del presidente que había dejado Oruro el día 24 y se dirigía a La Paz con una Secretaría de Guerra a cargo de Manuel Macedonio Salinas. Pérez y Carvajal despacharon un correo extraordinario a Achá comunicándole cómo la intervención del vecindario congregado en una junta había logrado el restablecimiento del orden constitucional. Contento por ello, en las proximidades de la ciudad, Achá recibió a varias corporaciones encargadas de pedir la amnistía para los sublevados a fin de evitar «nuevos horrores». Entre ellas destacaba la Sociedad del Orden. Esta asociación se había organizado el 26 de noviembre para «crear opinión a favor del orden legal y defender la legitimidad de los poderes constitucionales». Entre sus cometidos figuraban reordenar la ciudad, asentar a sus autoridades y controlar tanto el poder popular como las acciones militares ${ }^{52}$. Su protagonismo en las conversaciones entre Achá y los rebeldes entre el 27 y 29 de noviembre incidió en el hecho de que la junta y sus notables organizados asociativamente canalizaban a su favor la acción del pueblo movilizado contra Yáñez e impedían el reconocimiento de una victoria militar como el medio de acceder al gobierno. La fórmula pueblo armado-vecindario asociado había resuelto en clave civil a favor del gobierno un conflicto militar. Ahora el pueblo instituido en una junta asumía su poder por encima de la acción de militares que estaban acostumbrados a justificar sus sublevaciones en que el pueblo había depositado en ellos sus garantías. Los actos de Yáñez y la rebelión de Balza, tuvieran o no un mismo origen, expresaban un exceso de celo partidista que impedía la legitimidad gubernamental de quienes lo ejercieran. En contraste, la política de fusión de Achá53 se tornaba otra vez en la solución para regular el acceso al poder y su disfrute partidario, quedando reforzada a través de gestos como la amnistía general aceptada por el presidente a instancias de la Sociedad del Orden y la admisión de las fuerzas rebeldes en el ejército constitucional. En consecuencia y en contraste con lo sucedido en agosto, Achá entró en la ciudad fortalecido en su cargo. Su paso fue acompañado por una

52 René-Moreno, 1954: 219-223.

53 El Pueblo, Sucre, 9 de noviembre de 1861: 1-4; 20 de noviembre de 1861: 1-2. 
población que daba vivas a la Constitución y gritaba «mueran los rebeldes argentinos, mueran los asesinos» ${ }^{54}$.

El fracaso del pronunciamiento del 30 de noviembre del ex ministro Fernández en Sucre y de otros septembristas disidentes supuso una confirmación de la autoridad de Achá en las diferentes localidades bolivianas, tanto por parte de autoridades civiles y militares como de la población que se había alzado en armas para defender el orden constitucional ${ }^{55}$. Asimismo, la posterior victoria sobre motines belcistas, como el del 7 de marzo de 1862 en Sucre, favoreció un hermanamiento entre los septembristas ${ }^{56}$. Sin embargo, ello no conllevó que Achá pudiera llevar a cabo una reforma militar que redujera y profesionalizase el ejército, con lo que la rutina de las sublevaciones militares se mantuvo aunque sus fundamentos legitimadores hubieran sido debilitados. Mientras el gobierno hacía frente a los asuntos bélicos, el caso Yáñez cobró un lugar central en el proceso de pacificación nacional. Éste exigía el resarcimiento a las víctimas y el develamiento judicial de lo sucedido. Respecto a lo primero, el 3 de diciembre se decretó una pensión alimenticia sobre las rentas del tesoro público del departamento de La Paz a las viudas y huérfanos de los ejecutados el 23 de septiembre, y se concedió educación gratuita a los hijos de éstos en colegios y universidades ${ }^{57}$. Respecto a lo segundo, René-Moreno señala que no existió un proceso especial sobre el suceso, pero sí autos militares a algunos cómplices de Yáñez — no como tales, sino como reos de delitos privados aquella noche - debido al clamor popular que exigía juzgarlos. Ello permitió una revisión de los autos militares realizados por orden de Yáñez entre el 29 de septiembre y el 23 de octubre y a propósito de la revolución de ese mismo día. Como resultado, en la Orden General del 2 de diciembre de 1861 Achá consideró punible lo sucedido el día 23. Fueron borrados de la lista militar casi todos aquellos para quienes Yáñez había propuesto un ascenso, como el coronel Francisco Benavente, el teniente coronel graduado Santos Cárdenas, el sargento mayor Demetrio Urdininea y el capitán Antonio Gutiérrez, por haber coadyuvado a los asesinatos. El alcalde de la cárcel pública José María Aparicio y el fiscal Pedro Cueto fueron expulsados de su cargo por ignominia ${ }^{58}$.

\footnotetext{
54 Fernández, Flores y Balza eran de origen argentino. Julio Méndez, «Carta a Yáñez», El Constitucional, La Paz, 12 de mayo de 1862.

55 El Constitucional, La Paz, 7, 11 de diciembre de 1861

56 ABNB. Ruck 415.

57 El Constitucional, La Paz, 7 de diciembre de 1861.

58 «Primer Sumario levantado en 1864. Secretaría General sección justicia, Oruro 23 de diciembre de 1861», Las matanzas del Loreto ejecutadas en La Paz la noche del 23 de octubre de 1861 por el coronel Plácido Yáñez, Cochabamba, Imp. Del Siglo, 1871: 16-37, ABNB. M413.
} 
Aunque esas medidas no fueron suficientes para muchos belcistas y la responsabilidad de Achá en lo hecho por Yáñez intentó ser probada por sus detractores $^{59}$, el 18 de octubre de 1864 el Congreso rechazó los cargos relativos a Achá por las matanzas, estableciéndose que: primero, los asesinatos del 23 fueron obra exclusiva de Yáñez; segundo, si hubo algún cómplice perteneciente al gobierno ese no fue Achá (tampoco pudo demostrarse que fuese Fernández) ${ }^{60}$; $\mathrm{y}$, tercero, Achá no dio nunca aprobación a la hecatombe sangrienta y que si no la condenó en un inicio y castigó como correspondía fue porque su autoridad estaba amenazada por los miembros de su gabinete ${ }^{61}$.

Historiográficamente se ha dicho que las guerras civiles habían «corrompido excesivamente las costumbres de la época» y que los sucesos narrados mostraban un «pueblo de La Paz (...) acéfalo», «levantado de modo espontáneo» ante la «apatía y la abyección» demostrados en los días de las matanzas por las autoridades citadinas y por el «vecindario acomodado». Ante ello la plebe «reasumió tumultuariamente la soberanía para el solo acto de hacer justicia de Dios linchando a los culpados». Mientras esto sucedía, «el vecindario no asomó cabeza en esto para nada» y sólo hizo «presencia en un comicio político después de ejecutado Yáñez» porque «la ira popular» obligaba «a mantener a flote la nave política» ${ }^{62}$. Frente a lo anterior, no hay duda de que «la clase popular» o «la cholada» fue el principal actor político del momento y que gracias a su acción y también por temor a ella pudo haber una movilización posterior de otros sectores. Sin embargo, ello no es contrario a que la manifestación popular contase con una mayor estructuración que la aparente. La forma de resolución del conflicto que se ha expuesto hace pensar que durante el mes transcurrido entre la Matanza del Loreto y la muerte de Yáñez hubo un proceso organizativo encaminado a liberar a los presos y destituir al tirano. Ya en el apartado anterior se ha mencionado como familiares y correligionarios belcistas dentro y fuera de La Paz habían tratado de concienciar a la población de los excesos de Yáñez para forzar su deposición. La rápida formación de una junta

59 Asunto de la correspondencia falsificada de Yáñez por su hijo Darío para vindicar su memoria: «Segundo Sumario levantado en 1864. Ministerio de Estado en el Despacho de Justicia e Instrucción- Cochabamba, 15 de octubre de 1864», Las matanzas del Loreto ejecutadas en La Paz la noche del 23 de octubre de 1861 por el coronel Plácido Yáñez, Cochabamba, Imp. Del Siglo, 1871: 16-37, ABNB. M413.

60 El Juicio Público se empeñó en probar sin éxito la culpabilidad de Fernández.

61 Juan M. Muñoz Cabrera, «Espléndida vindicación del presidente de la República José María de Achá», Las matanzas del Loreto ejecutadas en La Paz la noche del 23 de octubre de 1861 por el coronel Plácido Yáñez, Cochabamba, Imp. Del Siglo, 1871: 1-4, ABNB. M413.

62 Alcázar, 1988: 77-89. Aranzaes, 1992: 162-176. René-Moreno, 1954: 155. Sotomayor, 1874: 226. 
amparada en un pueblo armado frente a las fuerzas victoriosas de Balza hace también pensar que existía un posible coordinación entre el pueblo que ejerció violencia contra Yáñez y el que se reunió en el Loreto a discutir sobre la legitimidad de la asonada. ¿Quiénes lo componían?

A juzgar por los relatos periodísticos publicados desde los primeros encarcelamientos el 27 de septiembre hasta la entrada triunfal de Achá en La Paz el 30 de noviembre, los integrantes de ese pueblo eran las autoridades municipales, las corporaciones y el vecindario de La Paz. De este conjunto sobresalía «la clase de artesanos» integrada por menestrales agremiados, lo que dejaba en un segundo plano de acción pública popular a otro tipo de trabajadores cada vez más presentes en la ciudad. Este colectivo fue el principal protagonista de los discursos, arengas y proclamas hechas por las dos autoridades supremas de la ciudad hasta la llegada de Achá: el jefe político Carvajal y el general Pérez. Ambos dijeron que el triunfo de la Constitución no hubiera sido posible sin «las inspiraciones y cooperación» de su patriotismo, por lo que les pedían que se constituyeran en el «mejor centinela de la propiedad». De ese modo desmentirían todas las acusaciones que se habían vertido contra ellos referentes a su ignorancia e inmoralidad ${ }^{63}$. Identificados también como miembros de los tumultos callejeros a favor de Córdoba, de la «cholada persecutora» de Yáñez o de la «turba enloquecida» que no secundó la sublevación de Balza y Fernández, la acción de los artesanos quiso ser vista en todo momento como ligada exclusivamente a los excesos autoritarios y sangrientos de Yáñez. De hecho, el trabajo de René-Moreno alude a una reacción espontánea de un pueblo indignado que castiga la atrocidad de una matanza e instintivamente defiende las instituciones republicanas, siendo los vecinos notables los que reconducen la furia popular en clave constitucional.

Sin embargo, las medidas que dictó Achá en 1862 referentes tanto a subrayar el alcance nacional de la exposición local de artefactos -Alacitas-, como a organizar la guardia nacional, compuesta por «letrados, estudiantes, comerciantes y artesanos», en suspenso desde octubre de $1861^{64}$ hacen pensar que los manifestantes tenían mayores razones para ejercer la violencia política que un simple desahogo de «los bajos instintos desatados». Esto es, el movimiento de pueblo no fue tan espontáneo ${ }^{65}$. No sólo pudo estar orquestado con antelación, sino también estar favorecido por motivaciones que iban más allá

63 El Constitucional, La Paz, 2, 11 de diciembre de 1861; 20 de febrero de 1862.

64 Sotomayor, 1874: 247 y 511-512.

65 Sobre la crisis de la estructura de la sociedad tradicional y la acción política popular consúltense los argumentos de los pioneros y sugerentes textos de Giesecke, 1978, y de Romero, 5 (La Paz, 1984): 163-180. 
del odio a Yáñez y que identificaban a la acción política en la calle en defensa de la constitucionalidad como un modo de detener un proceso de devaluación social.

La primera medida informaba de que gremios artesanales estaban descontentos ante la pérdida de estatus por la competencia de las manufacturas extranjeras y el aumento de la mano de obra no agremiada en un contexto internacional de circulación de la creciente producción y del capital a escala mundial. Eran conscientes de estar amenazados por los efectos de la industrialización de ultramar, por la legislación ambigua y por la competencia entre los agremiados y las nuevas clases trabajadoras al no contar con una protección que limitara corporativamente el acceso al trabajo. Ante esa situación de indefensión y devaluación profesionales, los artesanos optaron por tornarse en un colectivo políticamente útil en dos niveles: por medio de las asociaciones y por medio de la toma de la calle ${ }^{66}$. Es decir, parte de la población paceña tenía un malestar propio que esperaba ser solucionado a través de su participación en los partidos políticos y su vinculación con las instancias de autoridad de la ciudad.

La segunda medida también estaba destinada a combatir la devaluación social, ya que las guardias cívicas conllevaban nuevas reubicaciones de estatus. Frente a la devaluación del artesano, su participación en éstas les permitía una alternativa de trabajo remunerada fija y regular que generaba independencia económica y favorecía su reconocimiento social por parte de la comunidad en clave patriota. En este sentido, la actitud obsequiosa de Achá a través de la celebración banquetes en el palacio en los que compartía mesa con los maestros mayores de diferentes gremios, de los que alababa «su nunca desmentida disposición para defender las instituciones y las autoridades legales» informaba que su apoyo en la derrota de Balza les convertía en actores políticos claves en las luchas partidarias. Con lo que la política se constituía en un arma de lucha contra el desempleo y el alza de precios, contra la proletarización y también contra la pauperización sin proletarización.

A solicitud de algunos artesanos paceños, ambas medidas fueron acompañadas de un indulto general para muchos compañeros encarcelados, siendo todas ellas interpretadas como un esfuerzo de dignificación del colectivo por parte del gobierno. Después de la muerte de Yáñez corrían rumores que presentaban a «la cholada con designios de perturbar el orden invocando a Belzu»

\footnotetext{
66 No es casual que en esta época, para evitar los brotes de violencia entre grupos con incompatibilidad de intereses en un mercado de trabajo limitado, se quisieran generar nuevas fuentes de trabajo productivas como redistribución de las tierras aptas para el consumo, en su mayoría tierras de comunidad indígenas (Langer y Jackson, 1990. Irurozqui, 2006b).
} 
por estar siempre dispuesta a hacer alboroto a cambio del dinero de los que querían atentar contra el gobierno. Ante la posibilidad de que a tenor de ese discurso se castigara a «los cholos» por lo sucedido, hubo un movimiento urbano de reivindicación pública. En él se inscribían las declaraciones en la prensa de los maestros mayores de diferentes gremios acerca de «los que subsistimos de nuestro trabajo no deseamos ningún cambio político y nos hallamos resueltos a sostener al gobierno legal bajo la salvaguarda de la constitución que ofrece toda clase de garantías, hasta que la nación elija al presidente constitucional por medio de sufragios». Este ofrecimiento al gobierno de sostenerlo igual que en la mañana del 23 de noviembre informaba de: primero, la necesidad de los artesanos agremiados de asumirse como «el pueblo de La Paz» y lograr a través de esa resignificación identitaria no sólo diferenciarse de aquellos otros colectivos que competían laboralmente con ellos, sino también desacreditarlos mediante su identificación con «la turba que se compraba para las revoluciones», «el populacho sin sentimientos de honor»o «la plebe deshabituada al trabajo»; segundo, «la noble y generosa clase de artesanos» era consciente de su importancia en las reyertas partidarias, con lo que la invocación de su pasado belcista también actuaba de recordatorio para Achá de las consecuencias que podría tener para el gobierno desatender sus reclamaciones laborales y de estatus; y, tercero, la oferta política hecha por los artesanos «de amar la paz y el orden»y, por tanto, de apoyar la candidatura de Achá en las elecciones de mayo de 1862 se mantendría mientras en su programa de gobierno figurase su defensa corporativa, con lo que su dignificación social pasaba por el ejercicio de la política ${ }^{67}$. En este sentido, la prédica fusionista de Achá de abandono de «la senda revolucionaria y el desorden» no se entendía ni se traducía como en la época de Linares en una despolitización de la población que debía consagrarse «a la industria y a la explotación de suelo virgen y fecundo de la madre patria» ${ }^{68}$. Al contrario, se buscaba lograr una incorporación partidista del pueblo a la vida pública en la que el ciudadano armado organizado en asociaciones y guardias cívicas impediría los motines militares. Éstos, en contraposición a las revoluciones «condición y constancia de todo progreso», se asumirían como una «perturbación violenta, transitoria e ilegítima de un reconocido y organizado orden social» ${ }^{69}$. Y éste quedaba salvaguardado por un uso civil de la violencia que se reduciría al mínimo si se concretaba la politización del pueblo o desarrollo en ella de espíritu público.

\footnotetext{
67 El Constitucional, 18 y 23 de diciembre de 1861; 15 y 25 de febrero de 1862.

68 El Artesano de Sucre. Sucre, 6 de enero de 1858; 27 de marzo de 1858, 10 de abril de 1858.

69 Villamil, 1858: 43-37.
} 


\section{CONCLUSIONES}

Este texto ha abordado los procesos conjuntos de institucionalización del Estado y de institucionalización de la soberanía popular a través del estudio de la violencia política que se asocia a comportamientos cívicos y está encarnada en el ciudadano armado. En la década de 1860, la política de fusión de Achá se asentó como la solución gubernamental destinada a garantizar la gobernabilidad de Bolivia. Se trataba de combatir la militarización de la política mediante la corrección de dos males vinculados «al espíritu de partido»: la negativa del partido vencido a reconocer su derrota y la negativa del partido vencedor a hacer concesiones a sus rivales. El caso de la Matanza del Loreto ha ilustrado que el éxito en su cuestionamiento social provino de la conversión del vecindario paceño en el pueblo en armas. El ejercicio popular de la violencia contrarrestó y deslegitimó tanto el abuso partidista del poder realizado por Yáñez en nombre del orden público, como la ruptura de la legalidad constitucional ejercida por la revolución de Balza. El pueblo armado en la calle y el pueblo congregado en el cabildo y organizado en una junta constituyeron la respuesta al militarismo pretoriano responsable de los golpes de Estado y revoluciones que afectaban la gobernabilidad de la república. Con ello ayudaron a asentar la política de fusión y a desacreditar el constante recurso de la guerra como modo de regular la competencia partidaria y la sucesión en el poder.

Las elecciones presidenciales y del congreso legislador celebradas el primer domingo de mayo de 1862 ratificaron a Achá como presidente. En 1866 fue derrocado por uno de sus hombres de confianza, Mariano Melgarejo (1866-1870), mediante un golpe ministerial. Si bien el uso de la fuerza siguió siendo un modo legítimo de alcanzar la presidencia siempre que fuera acompañado de comicios y reformas constitucionales, la figura del ciudadano armado asociada a la acción de los líderes militares perdió entidad como quedó evidenciado en la revolución de 1870 que lo destituyó ${ }^{70}$. El lugar de los jefes militares en la transformación del escenario político fue ocupado por los civiles armados, cuya acción dejó de vincularse a una revolución militar para circunscribirse a la defensa autónoma del orden constitucional. Ello no significaba que los militares dejaran de intervenir en la política ni que la población no emplease la fuerza, sino que los primeros ejercían la violencia en compañía de un pueblo que no delegaba su soberanía en ellos y que se consideraba el responsable último de la acción del ejército. 2006a)

70 Sobre la participación armada de los indígenas del Altiplano véase Irurozqui, 26 (Quito, 
Si la libertad se asociaba estrechamente con la participación en la vida pública, el problema era ahora cómo lograr un equilibrio entre el pueblo en armas defensor de la ley y la institucionalización de la vida política a fin de que las contradicciones políticas se expresasen por canales ajenos a la violencia y que la acción en la calle de los movimientos sociales no impidiese la gobernabilidad de la República. Paradójicamente, la Guerra del Pacífico (1879-1881) impuso la pacificación de la política como forma de regeneración nacional frente a los desastres bélicos. Las posteriores desciudadanización del soldado y desmilitarización de la población informaban de una lucha entre civiles armados y militares por establecer quiénes eran los guardianes de la nación que tuvo como resultado una activación del proceso de profesionalización del ejército, una política constitucional más duradera y una deslegitimación de la acción popular no canalizada mediante elecciones ${ }^{71}$. Consecuencia parcial de la domesticación de la violencia ejercida por el ciudadano armado ha sido el entendimiento de la democracia más como el imperio del estado de derecho que como el triunfo de la soberanía popular, siendo comprensible por qué el actual debate sobre la resignificación conceptual de la ciudadanía se ha interesado en las polémicas decimonónicas sobre el tema.

\section{BIBLIOGRAFÍA}

Alcázar, Moisés, Páginas de sangre, La Paz, Ed. Juventud, 1988.

Aranzaes, Nicanor, Las revoluciones en Bolivia, La Paz, Ed. Juventud, 1992.

Arguedas, Alcides, Historia de Bolivia. La dictadura y la anarquía, Libro II, Madrid, Aguilar, 1959.

Calderón Jemio, Raúl, La rebelión de 1858-1860 en la provincial de Omasuyos, La Paz, E. G., 1993.

Calderón Jemio, Raúl, «En defensa de la dignidad: el apoyo de los ayllus de Umasuyu al proyecto belcista durante su consolidación (1848-1849)», Estudios Bolivianos 2 (La Paz, 1996): 99-110.

Carvajal, Rudesindo, Breve exposición de mis circunstancias públicas y privadas como Jefe Político de la ciudad de La Paz en el último trimestre de 1861, Sucre, Tip. Pedro España, 1864.

Dunkerley, James, Orígenes del poder militar en Bolivia. Historia del ejército, 1879-1935, La Paz, Ed. Quipus, 1987.

\footnotetext{
71 Dunkerley, 1987: 11-33; Irurozqui, 2009; Quintana, 1998: 15-74.
} 
El Alacita, Crónica de los tres últimos meses de 1861 con una carta misteriosa de Plácido Yáñez a Ruperto Fernández datada en la eternidad, La Paz, Imp. de Alacitas, 1862.

Giesecke, Margarita, Masas urbanas y rebelión en la Historia. Golpe de Estado, Lima 1872, Lima, CEDHP, 1978.

Irurozqui, Marta, La ciudadanía en debate en América Latina. Discusiones historiográficas y una propuesta teórica sobre el valor público de la infracción electoral, Lima, IEP, 2005.

Irurozqui, Marta, «¿Ciudadanos armados o traidores a la patria? Participación indígena en las revoluciones bolivianas de 1870 y 1899», Iconos. Revista de Ciencias Sociales 26 (Quito, 2006a): 35-46.

Irurozqui, Marta, «Sobre el tributo y otros atributos ciudadanos. Sufragio censitario, fiscalidad y comunidades indias en Bolivia, 1825-1839», Bicentenario. Revista de Chile y de América 5/2. (Santiago de Chile, 2006b): 35-66.

Irurozqui, Marta, «Del "Acta de los Doctores" al "Plan de Gobierno". Las Juntas en la Audiencia de Charcas (1808-1810)», Manuel Chust (ed.), 1808: la eclosión juntera en el mundo hispano, México, FCE, 2007, pp. 192-226.

Irurozqui, Marta, «El espejismo de la exclusión. Reflexiones conceptuales acerca de la ciudadanía y el sufragio censitario a partir del caso boliviano», Madrid, Ayer, 70/2, (Madrid, 2008): pp. 57-92.

Irurozqui, Marta, «Un mar de sangre para renacer. Bolivia y la Guerra del Pacífico», José Antonio Chaupis (ed.), La Guerra del Pacifico 1879-1883, Lima, Universidad Mayor de San Marcos, 2009 (en prensa).

Irurozqui, Marta y Víctor Peralta, «Ni letrados ni bárbaros. Caudillos militares y elecciones en Bolivia, 1826-1880», Secuencia. Revista de Historia y Ciencias Sociales, 42 (México, 1998): 147-176.

Langer, Erick y Robert Jackson, «El liberalismo y el problema de la tierra en Bolivia, 1825-1820), Siglo XIX, 10 (Monterrey, 1990): 9-32.

Ligera exposición de los últimos acontecimientos de Bolivia, Potosí, Imp. Republicana, 1861.

Peralta, Víctor y Marta Irurozqui, Por la Concordia, la Fusión y el Unitarismo. Estado y caudillismo en Bolivia, 1825-1880, Madrid, CSIC, 2000.

Quintana Taborga, Juan R., Soldados y ciudadanos. Un estudio crítico sobre el servicio militar obligatorio en Bolivia. La Paz, PIEB, 1998.

René-Moreno, Gabriel, Anales de la Prensa boliviana. Las matanzas de Yáñez. Potosí, Casa Nacional de Moneda, 1954 (1884-1885).

René-Moreno, Gabriel, Anales de la prensa boliviana. El golpe de Estado de 1861, La Paz, 1985. 
Richard, Frédéric, «Política, religión y modernidad en Bolivia en la época de Belzu», Rossana Barragán, Dora Cajías y Seemin Qayum (comps.), El siglo XIX en Bolivia y América Latina, La Paz, IFEA-Muela del Diablo-CH, 1997: 619-634.

Rodríguez Ostria, Gustavo, Estado y Municipio en Bolivia. La Ley de participación popular en perspectiva histórica, La Paz, MDSYMA, 1995.

Romero Pittari, Salvador, «Copetudos y sin chaqueta: la revolución federal de Andrés Ibáñez», Historia y Cultura, 5 (La Paz, 1984): 163-180.

Rosanvallon, Pierre, Le people introuvable. Histoire de la représentation démocratique en France, París, Gallimard, 1998.

Sábato, Hilda, «"Resistir la imposición”: revolución, ciudadanía y República en la Argentina de 1880», Revista de Indias, LXIX/246 (Madrid, 2009): 159-181.

Schelchkov, Andrey, La utopía social conservadora en Bolivia: el gobierno de Manuel Isidoro Belzu 1848-1855, Moscú, Academia de Ciencias de Moscú, 2007.

Sotomayor Valdés, Ramón, Estudio Histórico de Bolivia bajo la administración del general José María de Achá con una introducción que contiene el compendio de la guerra de la Independencia y de los gobiernos de dicha república hasta 1861, Santiago, Imp. Andrés Bello, 1874.

Ternavasio, Marcela, «La visibilidad del consenso. Representaciones en torno al sufragio en la primera mitad del siglo XIX», Hilda Sábato y Alberto Lettieri (comps.), La vida política en la Argentina del siglo XIX. Armas, votos y voces, Buenos Aires, FCE, 2003: 57-73.

Thibaud, Clément, «Definiendo el sujeto de la soberanía: repúblicas y guerra en la Nueva Granada y Venezuela 1808-1820», Manuel Chust y Juan Marchena (eds.), Las armas de la nación. Independencia y ciudadanía en Hispanoamérica (1750-1850), Madrid-Fráncfort, Iberoamericana-Vervuert, 2008: 185-221.

Villamil, Emeterio, Juicio de la revolución de Linares por D. Emeterio Villamil, Presidente de la Cámara Constitucional de Representantes de Bolivia, Arequipa, Imp. de Francisco Ibáñez y Herms., 1858. 


\section{DEATH IN EL LORETO. ARMED CITIZENRY AND POLITICAL VIOLENCE IN BOLIVIA (1861-1862)}

The «Loreto Massacre» and the subsequent process of popular justice to which its author was brought illustrate how the arming of the inhabitants of this district of La Paz combated not only the partisan abuse of power, but also the threat posed to Bolivia's constitutional legal framework by military revolutions. In a process of "political fusion», the "people on the streets》 and the people as represented by the government took armed and associative action against an attempted military coup. This process also implied the employment of political action as an instrument against the devaluation of labour and artisan production.

Key words: Yáñez Slaughter, Armed Citizen, Fusion Policy, Assembly, Town Council, Militarism Revolution, People, Craftsmen, Bolivia. 